\title{
An introduction to EU administrative governance
}

\section{Herwig C.H. Hofmann and Alexander H. Türk}

The discussion about the transformation of forms of government and governance in Europe, can never avoid touching upon the role of administrations or administrative actors and with good reason - within the EU's multi-level system, the activities of agenda setting, policy formulation and implementation all involve some form of interaction between public actors from the sub-national, national, supranational and international levels.

The interaction between administrative institutions within the EU constitutes a core feature of today's reality of EU multilevel governance. Co-operation amongst administrations in Europe has become the backbone of the EU's unique system of government and governance. Yet, this feature, as many aspects of administrative law and policy in the EU, has developed in an evolutionary fashion and is rarely explored in a cohesive manner.

\section{THE NOTION OF ADMINISTRATIVE ACTION IN THE EU}

Traditionally, administrative action is associated with implementation of policies defined in laws or other government programmes. As we describe in the chapter on implementation, the rules and procedures governing this type of administrative action can be analysed both from what we refer to as an 'external' and an 'internal' point of view. ${ }^{1}$ The 'external' point of view is the more traditional, lawyerly perspective, describing the rules and procedures that lead to the creation of externally binding decisions and other forms of administrative activity.

From what we describe as an 'external' point of view, European administrative law has been categorised as three distinct sets of legal provisions. ${ }^{2}$ The first set of legal rules and principles governs the execution of EU law by its own institutions, either for internal administration or for

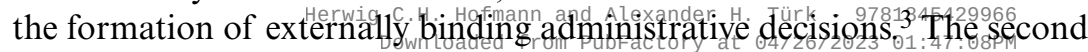


governs the enforcement of European law by national authorities. These latter rules are essentially rules created by the Member States but are heavily influenced and modified by European legal rules and principles. They are often referred to as a body of 'Europeanised' administrative law. The third group is an area of law without direct contact with the implementation of EC law, but where nevertheless EU law has influenced the legal developments of national law and thereby transformed the national legal systems. ${ }^{4}$ None of these areas of administrative law have been systematically codified. All three are the result of very specific legislation together with general principles of law mainly developed in the case law of the ECJ. ${ }^{5}$

Although this classification is helpful to understand the different layers of 'Europeanisation' of administrative law in Europe, what is generally missing from this picture is what we refer to in the implementation chapter as the 'internal' point of view. The problem with the external point of view is that despite its clarity and usefulness as an analytical tool for the understanding of forms of administrative law in Europe, it does not address the other extremely important functions, which administrations have in Europe. These functions are more hidden from the external view. They are essentially the co-ordinating and structuring roles which administrations play in all phases of what, in political science literature, is often referred to as the 'policy cycle' - the phases of agenda setting, policy formulation and finally implementation.

The question therefore arises as to how to include the internal point of view in our picture of administrative action in the EU. The goal is to capture, analyse and evaluate this essential feature of administrative action in the EU and to get an understanding of the different forms of administrative governance in the EU. As a starting point for our investigation, we undertake to do so by juxtaposing the concept of 'executive federalism' on the one hand with the notion of 'networks of administration' on the other.

The notion of executive federalism has traditionally been employed to help illustrate the relationship between the multiple levels of administration in the EU. Within this system, administration on the European level-mainly the Commission but also to a certain degree the Council but both with the help of national administrations - has been regarded as primarily engaged in conception of policies rather than their enforcement. ${ }^{6}$ The European level was expected to be involved in enforcement only in certain clearly defined areas such as competition law and budgetary matters. In other matters, Member States' administrations fulfil the role of enforcement agencies. This concept is of course a helpful simplification to understand the concepts enshrined in the basic provisions of the EC treaty's executive activities. ${ }^{7}$ However, this helpful simplification of the notion of executive federalism

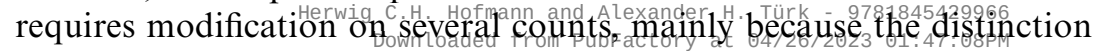


between the Member State and the EU is not as clear cut in reality as the notion of 'federalism' in executive federalism might lead some unacquainted onlookers to believe - this model is akin to a simple view of understanding the EU as a multi-level system distinguishing mainly between the EU and the Member State level.

In the reality of today's EU system there is intensive co-operation of administration in all phases of the policy cycle from agenda setting over decision making to implementation of policies. In fact, both with regard to the structure of administrative co-operation as well as to its effects, the analysis of this book will show the dimensions of the sphere of joint, and in many cases integrated, administration in Europe. The structural notion is that since the very beginnings of the development of common policies in the EC, the need for co-operation of administrations within the system of administrative federalism existed. These practical requirements of co-ordination of enforcement have led to the continual and ongoing development of a multitude of institutional structures and ad hoc policy solutions, which political scientists have labelled as the EU administrative network. The term administrative network, therefore, although beset with a degree of vagueness, has the advantage of being all encompassing. With this openness, it allows us to focus on the shortcomings of the above-mentioned attempts to categorise both the internal and the external dimension of administrative law in Europe.

Network is a term that in political science and beyond is used in different contexts. As an analytical category, it is defined as an entity in which different parts are loosely linked, but not fixed together. The single elements are autonomous from, yet not necessarily equal to each other. ${ }^{8}$ As a metaphor, network tends to stand for any structure that is not strictly hierarchical. In this context, we use both notions, but in different contexts. When we speak of the EU administrative network, we use the term in a metaphorical way to express that this administrative system is not an administrative hierarchy in the strict sense, even though it may contain hierarchical elements. When we speak of networks as specific structures distinct from agencies and committees, we refer to the above definition according to which a network (in the stricter sense) may not contain hierarchical elements.

The development of the European administrative networks has resulted from two fundamental needs: to link national and European administrations in order to maximise their problem solving capacity and to jointly exercise their executive power; and to allow for varying and finely tuned mixes of both formal and informal power of European and national collective actors and of different European institutions.

The evolution of various structures for the administrative network in

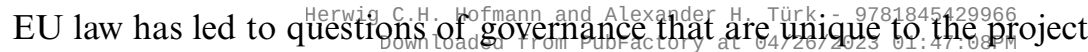


of European integration. They include considerations on diversification of administration on the EU-level through the development of agencies, their nature, role and future. ${ }^{9}$ They also include structural questions as to the accountability and transparency of comitology as well as more procedural questions such as for example how to structure the interface between scientific expertise and political decision-making and how to conduct effective knowledge management within the network. ${ }^{10}$ The development of network administration also has consequences for supervision and control of executive activity. This book on EU Administrative Governance seeks to review the functions of administration in Europe with respect to these tasks in all phases of the policy process throughout the various policy areas. It reflects on the reality that the notion of administration in the EU has undergone considerable historic change.

\section{THE NOTION OF GOVERNANCE IN THE CONTEXT OF EU ADMINISTRATION}

Scholars of the field of governance and government are familiar with the fact that the academic debate contains a wide spectrum of more or less precise definitions for the term 'governance'. ${ }^{11}$ With respect to our study of EU administrative governance we observe that, at one end of the spectrum, governance is simply defined as the exercise of public power, that is what governing institutions (but not necessarily governments) do. ${ }^{12}$ At the opposite end, governance is used to describe a very particular form of steering, in which public and private actors interact in an open way in order to reach common public policy aims. Between these definitions we find governance often used to denote mechanisms of 'governing or steering' not exercised solely by governments, but including the governing and regulatory activities of different governmental, quasi- or semi-governmental as well as non-governmental actors. Governance in this sense is not only performed by hierarchical mechanisms of legally binding acts, but also includes methods such as soft law, agreements and contracts. It is exercised in configurations with regional, supranational and international governmental institutions working complementarily or in co-operation with national governments. The exact configurations depend on the policy area involved and the rules and practices developed for its administration.

In this respect, the term governance is not only a factual description but also indicates the use of an analytical perspective. It involves a comprehensive understanding of the reality of the exercise of public duties through broadening the analytical perspective beyond results by focusing more strongly on the procedures within the Hofmann 
in our book we deal with a reality of public administration that is different and to a certain degree more complex than what we know about the public administration of the EU-member states. It is trans-national by nature and covers a highly complex structure of more or less formalized administrative entities. It includes the participation of a multitude of governmental, semigovernmental and non-governmental actors in different roles.

The changed analytical perspective also allows us to focus on an additional feature of the development of governance structures involving administrative actors in the EU: the changing nature of governance structures over time. The EU, which has been designed from its very beginnings as an experimental undertaking, is searching for 'new forms of governance'. New and existing forms of governance are being adapted and are adaptable to both the necessities of new policies to be addressed on the European level and to an increasing amount to member states. Governance structures are therefore by no means static. They are the result of evolutionary developments in the various policy areas. ${ }^{13}$ To some degree the challenge of studying administrative cooperation in the EU and forms of EU administrative governance results exactly from the non-static, evolutionary nature of the governance structures and their diversity. The use of the term governance allows us to address the open and dynamic development of steering tools and procedures, which often span the divide between political and legal structures. ${ }^{14}$

However, when governance structures have been developed and are being applied in a given policy area, very legitimate questions inevitably arise as to the rules governing these structures. These questions address issues of accountability both by traditional means, through judicial and political control of administrations as well as by alternative means, which challenge the centrality of traditional modes of accountability concentrated primarily on parliamentary supervision and review of administrative action in courts. ${ }^{15}$ Such additional mechanisms of accountability include, for example, various methods of administrative co-operation such as bench-marking and policy competition both between regulatory levels and amongst different agencies and actors on the same regulatory level. ${ }^{16}$

By looking at the developing modes of administrative governance in this book we are therefore primarily addressing the procedural sides of administrative co-operation in the EU. The procedural aspect again has several dimensions. Joerges for example points out that governance is not so much only the design of procedures to achieve a certain predefined, intentional end. Instead, governance structures in Europe have often shifted their focus from "goal-oriented "intentional" strategies to strategies that place greater confidence in the ingenuity of the actors involved. ${ }^{\prime 17}$ This,

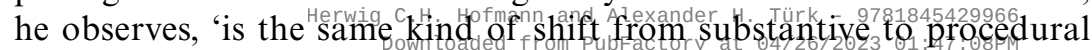


rationality which legal theorists suggested as a response to the failures of the interventionist legal policies and to which administrative lawyers refer whenever they diagnose the emergence of 'negotiated relationships between public and private actors' and 'public private partnerships' ${ }^{18}$

The double character of governance structures being both non-static and deeply procedural in nature also requires continuous reflection on the context in which law emerges as well as on the framework for the exercise of governance in the EU. We can define several factors that are relevant for a framework of procedural justice in administrative governance in the EU. These factors will re-emerge throughout the different chapters of the book. These factors are, first, the ability of the governance structures to structure the adequate input into the relevant procedures. This criterion is often referred to as 'input legitimacy' and requires the participation of relevant societal players, and the gathering of all necessary and correct information. The latter criterion is well-known to administrative lawyers from judicial review of discretionary decisions. Second, this information gathering requires the ability to computerise the information collected. Again, this is known in review of discretionary decisions as the criterion of whether the administration has taken not only all relevant information into account but also whether its decision-making was guided by considerations relevant to the decision at issue. Third, the procedures must be organised in order to allow for a satisfactory outcome. This criterion is what political science literature refers to as 'output' legitimacy - Can the procedure produce valuable results? The fourth factor is the question of whether there is the possibility of sufficient review and continuous control as well as evaluation of procedures and results. This factor is linked to the extensive accountability debate. Finally, proceduralisation also relies on the ability to steer governance structures, that is to hold the procedures accountable also to higher legal principles and to political will.

The goal of this book in this respect is to add to the understanding of the non-static, primarily procedural nature of governance structures in the EU. The use of the term governance in this sense allows us to take a wide analytical perspective to find out about the increasing variation in the functions of governing and [...] the diversity of institutional levels and actors involved.' 19 Equally, it is our goal with this book not to capitulate in the face of diversity and the multiple forms of governance. Instead, we intend to offer analytical perspectives of historic developments, studies of governance structures in different policy phases ('horizontal' topics), analysis of governance structures in single policy fields ('vertical' topics) and, finally, by offering analysis of what we might call 'diagonal' topics, looking at issues from democratic legitimacy to judicial review, from impact assessment to theories of deliberative and Alexanderionalirk- 9781845429966 


\section{NOTES}

1. We do not use the notions of 'external' or 'internal point of view' here in H.L.A. Hart's way, but to denote the simple existence of different perspectives for review of administrative law and administrative functions in the EU.

2. S. Kadelbach, 'European Administrative Law and the Law of a Europeanised Administration', in: C. Joerges, R. Dehousse, Good Governance in Europe's Integrated Market (Oxford: OUP, 2002), pp. 167-206.

3. Schwarze's groundbreaking work from the 1980s was an investigation into the origins and manifestations of essentially this part of EU administrative law. See, J. Schwarze, Europäisches Verwaltungsrecht (Baden-Baden: Nomos, 1988).

4. S. Kadelbach, supra note 2 .

5. All three however also have their very specific modes of interaction in the relation between the European and the national and sub-national levels. The first is granted effect through the principles of direct effect and supremacy. The second receives binding influence from the EC legislation which either transforms the national legal system or requires national law to be interpreted in conformity with EU law. Interactions with actors from other Member States or EU executive powers are regulated according to the rules of secondary legislation and general principles of EU law. Although the third category is not bound by EU law, it is a reaction of the transformation of legal systems. The interaction is regulated in the form of traditional rules of international administrative law, as a subsection of national conflicts rules.

6. L. Azoulay, 'The Judge and Administrative Governance', in: C. Joerges, R. Dehousse (eds), Good Governance in Europe's Integrated Market (Oxford: OUP, 2002), p. 110.

7. Such as for example Articles 10, 202 and 211 EC.

8. R. Mayntz, 'Policy-Netzwerke und die Logik von Verhandlungssystemen', in: A. Héritier (ed.): Policy-Analyse. Kritik und Neuorientierung (24 PVS-Sonderheft, 1993), p. 44; P. Kenis, V. Schneider, 'Policy Networks and Policy Analysis: Scrutinizing a New Analytical Toolbox', in: B. Marin, R. Mayntz (eds), Policy Networks, Empirical Evidence and Theoretical Considerations (Frankfurt am Main: Campus Verlag, 1991), p. 34.

9. Which includes considerations on the potential future of the 'Meroni-doctrine'.

10. R. Dehousse, 'Misfits: EU Law and the Law of a Europeanized Administration', in: C. Joerges, R. Dehousse (eds), Good Governance in Europe's Integrated Market (Oxford: OUP, 2002), p. 215.

11. See for example, J. Kooiman, Governing as Governance (London: Sage, 2003); R. Mayntz, 'Governance Theory als fortentwickelte Steuerungstheorie?', MPIfG Working Paper 2004/1, available at http://www.mpi-fg-koeln.mpg.de/pu/workpapers_de.html.

12. Accordingly, the word governance is supposed to originate in the Greek term kubernân which described the activity of steering a chariot or a ship.

13. As the development of the comitology committees from the 1960s to today's development of Lamfallussy procedures and agencies show.

14. An example is the so-called 'Open Method of Co-operation'.

15. C. Scott, 'Accountability in the Regulatory State', Journal of Law and Society 27 (2000), 38-60.

16. E.O. Eriksen, J.E. Fossum, 'Europe at the Crossroads: Government or Transnational Governance', in: C. Joerges, I.-J. Sand, G. Teubner (eds), Transnational Governance and Constitutionalism (Hart, Oxford, 2004), p. 120; J.H.H Weiler, I. Motoc, 'Taking Democracy Seriously: The Normative Challenges to the International Legal System', in: S. Griller (ed.), International Economic Governance and Non-Economic Concerns (Springer, Vienna, New York, 2003), p. 69.

17. C. Joerges, 'Constitutionalism and Transnational Governance: Exploring a Magic Triangle', in: C. Joerges, I.-J. Sand, G. Teubner (eds), Transnational Governance and Constitutionalism (Oxford: Hart, 2004), p. 368 .

18. C. Joerges, supra note 17. Downloaded from PubFactory at 04/26/2023 01:47:08PM 
19. I.-J. Sand, 'Polycontextuality as an alternative to Constitutionalism', in: C. Joerges, I.-J. Sand, G. Teubner (eds), Transnational Governance and Constitutionalism (Oxford: Hart, 2004), p. 45 et seq.

\section{REFERENCES}

L. Azoulay, 'The Judge and Administrative Governance', in: C. Joerges and R. Dehousse (eds.), Good Governance in Europe's Integrated Market (Oxford: OUP, 2002), pp. 109-37.

R. Dehousse, 'Misfits: EU Law and the Law of a Europeanized Administration', in: C. Joerges and R. Dehousse (eds.), Good Governance in Europe's Integrated Market (Oxford: OUP, 2002), pp. 207-29.

E.O. Eriksen and J.E. Fossum, 'Europe at the Crossroads: Government or Transnational Governance', in: C. Joerges, I.-J. Sand and G. Teubner (eds.), Transnational Governance and Constitutionalism, (Oxford: Hart, 2004), pp. 115-46.

C. Joerges, 'Constitutionalism and Transnational Governance: Exploring a Magic Trinagle', in: C. Joerges, I.-J. Sand and G. Teubner (eds.), Transnational Governance and Constitutionalism (Oxford: Hart, 2004), pp. 339-75.

C. Joerges, J. Neyer, 'From Intergovernmental Bargaining to Deliberative Political Processes: The Constitutionalisation of Comitology', European Law Journal, 273-99 (1997).

R. Mayntz, 'Policy-Netzwerke und die Logik von Verhandlungssystemen', in: A. Héritier (ed.), Policy-Analyse. Kritik und Neuorientierung (24 PVS-Sonderheft, 1993), pp. 39-56.

R. Mayntz, 'Governance Theory als fortentwickelte Steuerungstheorie?', MPIfG Working Paper (2004/1), available at http://www.mpi-fg-koeln.mpg.de/pu/ workpapers_de.html.

S. Kadelbach, 'European Administrative Law and the Law of a Europeanised Administration', in: C. Joerges and R. Dehousse, Good Governance in Europe's Integrated Market (Oxford: OUP, 2002), pp. 167-206.

P. Kenis and V. Schneider, 'Policy Networks and Policy Analysis: Scrutinizing a New Analytical Toolbox', in: B. Marin and R. Mayntz (eds.), Policy Networks, Empirical Evidence and Theoretical Considerations (Frankfurt am Main: Campus, 1991), pp. 25-59.

J. Kooiman, Governing as Governance (London: Sage, 2003).

I.-J. Sand, 'Polycontextuality as an Alternative to Constitutionalism', in: C. Joerges, I.-J. Sand and G. Teubner (eds.), Transnational Governance and Constitutionalism (Oxford: Hart, 2004), pp. 41-65.

C. Scott, 'Accountability in the Regulatory State', Journal of Law and Society, 27, 38-60 (2000).

J. Schwarze, Europäisches Verwaltungsrecht (Baden-Baden: Nomos, 1988).

J.H.H. Weiler and I. Motoc, 'Taking Demcoracy Seriously: The Normative Challenges to the International Legal System', in: S. Griller (ed.), International Economic Governance and Non-Economic Concerns (Vienna, New York: Springer, 2003), p. 69. 